\title{
If the Colour of Jesus Is not an Issue, why Are you so Incensed at the Suggestion that Jesus Is Black?
}

\author{
R. S. Tshaka \\ University of South Africa \\ tshakrs@unisa.ac.za
}

\section{Abstract}

Questions around the colour of Jesus are always received with reservations. Yet, not much is said about the colour of the very same Jesus that has come to adorn homes and places of worship of many black Christians across the globe. This article engages in a conversation about the colour of Jesus. It does this while being aware of the challenges that appear to be particular to black communities who seem to expect their salvation from those who do not look like them. The colour of Jesus has been a central issue for Black Theology of Liberation. This is because this theological hermeneutic was never able to relate to a god that was not sympathetic to their lived experiences.

Keywords: colour of Jesus; Iconography; Black Theology of Liberation; Black selfhate; Black Theology and Black Power

\section{Introduction}

This article is an attempt to restart a conversation on the debate around the colour of Jesus. It notes that the debate on the colour of Jesus is not an innocuous debate, but must be understood in the context of why there has been, over the ages, an intensive effort to project Jesus as white. ${ }^{1}$

1 Susannah Herschel in her book, The Aryan Jesus, reminds us why Jesus had to be stripped of his Jewishness and how that attempt at stripping Jesus gave birth to the idea of a racialised Jesus. The Nazis first needed to make a case for why Jesus was not a Jew but an Aryan, despite what the biblical texts teach us about Jesus and his culture (cf. S. Herschel, S. The Aryan Jesus: Christian Theologians and the Bible in Nazi Germany (Princeton: Princeton University Press), 2010.



Studia Historiae Ecclesiasticae https://upjournals.co.za/index.php/SHE/index Volume 46 | Number 1 | 2020 | \#6594 | 11 pages https://doi.org/10.25159/2412-4265/6594 ISSN2412-4265(Online)ISSN 1017-0499(Print)

(C) The Author(s) 2020

Published by the Church History Society of Southern Africa and Unisa Press. This is an Open Access article distributed under the terms of the Creative Commons Attribution-ShareAlike 4.0 International License (https://creativecommons.org/licenses/by-sa/4.0/) 
Understanding that Black Theology of Liberation (henceforth only referred to as Black Theology) was necessitated by white racism, and that Black Theology was a means towards a particular end, this article insists that the perception of the colour of Jesus has a direct impact on how black people view themselves and will continue to do so. The article engages the frustrations of Black Theology and responds to those who cynically disregard Black Theology for rejecting the white Jesus in dominant theological discourses. The article then proceeds to engage black self-hate. It makes a case for why this is apparent and why this needs to be arrested. Black self-hate is necessitated by iconography that at best encourages a flight from the black self. ${ }^{2}$ It is the view of the author that when one is bombarded with imagery which suggests that white aesthetics is normative, the consequent result is for those who are not in that category, to emulate that which is lifted up as the ideal.

A few suggestions are made at the end of the paper with the intention of insisting that for a people to fully appreciate themselves, they ought to have a theology that centres their lived experiences instead of emulating that which is irrelevant to their own contexts.

\section{The Frustrations of Black Theology in her Endeavours for Self-assertion}

In the preface to African Theology en Route, Kofi Appiah-Kubi of Ghana remembers the words of Psalm 137:4, "how can I sing the Lord's song in a strange land, in a strange language, in a strange thought, in a strange ideology?"3 Contextualising that sentiment, Appiah-Kubi was accentuating the view that the Christian faith must resonate with the lived experiences of the people on the African continent. He argues:

... for more than a decade now, the cry of the Psalmist has been the cry of many African Christians. We demand to serve the Lord in our own terms and without being turned into Euro-American or Semitic bastards before we do so. That the gospel has come to remain in Africa cannot be denied, but now our theological reflections must be addressed to the real contextual African situations. Our question must not be what Karl Barth, Karl Rahner, or any other Karl has to say, but rather what God would have us do in our living concrete condition. ${ }^{4}$

2 The notion of the "flight from the self" was first triggered by the analysis of renowned African American psychologist, Beverly Daniel Tatum. She refers to William Cross's psychology of nigresence or the psychology of becoming black. One of the first stages of becoming black, argues Tatum, is the stage of pre-encounter. In this stage, the black child absorbs many beliefs and values of the dominant white culture, including the idea that it is better to be white (cf. B. Tatum, "Why are All the Black Kids Sitting Together in the Cafeteria?" and other Conversations about Race (New York: Basic Books), 2003, 54-55. For further discussion of the notion, see R. S. Tshaka, "Do our Theological Methodologies Help us to Deal with Situations of Violence in Black Communities, specifically Afrophobia?" Journal of Theology for Southern Africa 138 (2010): 124-135.

3 K. Appiah-Kubi, "Preface." In African Theology en Route, edited by K. Appiah-Kubi and S. Torres (Maryknoll, Orbis Books), 1981, viii.

4 Appiah-Kubi, African Theology en Route, viii. 
These words were shared at an official gathering of African theologians in Ghana in 1977. They are words that are pregnant with a yearning for an African renaissance. It is impossible, therefore, to ignore the call for decoloniality and Africanisation when one takes these words seriously. Therefore, current attempts at placing the subject of decoloniality or Africanisation at its core in its reflections, must become aware of the fact that this call for Africanisation did not start recently, ${ }^{5}$ but has been an imploration from the heart in African scholarship since the 1960s and 1970s.

Sadly, African scholarship, in as far as it must foreground the lived experiences of Africans, ${ }^{6}$ is still engaged in a debate of whether or not the time is conducive for the decolonisation of a scholarship that is relevant to the people of this continent? This imploration by African scholars was continued in marginalised South African theological circles. In his $\mathrm{PhD}$ thesis, titled "Die Afgebreekte Skeidsmuur weer Opgebou"7 defended at the Vrije Universiteit in Amsterdam in 1982, Johannes Adonis makes a few prophetic statements which cannot be ignored today in the context of calls by the youth of South Africa that \#RhodesMustFall, ${ }^{8}$ and the calling for the radical transformation of education in South Africa. ${ }^{9}$

From the 17 Stellinge or statements that he makes, which was traditionally the practice once a person graduates with the highest degree in a Dutch university, I will refer to only three of these stellinge in an attempt to underscore the point this article wishes to make. Stelling 10 reads as such: "die dekolonisasie van die kerkgeskiedkrywing is ook in die Suid-Afrikaanse konteks " $n$ taak van die hoogste prioriteit." ${ }^{10}$ Statement number 15 reads movingly as follows: "indien die drie Swart Nederduitse Gereformeerde Kerke nie nou al intensief besig is met die ontwikkeling van 'n eie kontekstuele teologie nie,

5 Cf. K. Wiredu, “Toward Decolonizing African Philosophy and Religion.” African Studies Quarterly 1 (4) (1998): 17-46.

6 With the lived experiences, I am essentially referring to the experiences faced by black people, in particular, in all aspects of their existence. This does not only refer to how black people are treated by white people, but refers especially also to the very way that black people treat each other. Because black people have always been treated as second class human beings, this treatment has been imbibed by black people themselves and they are now the very ones who see each other as less human. So essentially the notion refers to the totality of black people's daily existence.

7 J. C. Adonis. Die Afgebreekte Skeidsmuur weer Opgebou: Die Verstrengeling van die Sendingbeleid van die Nederduitse Gereformeerde Kerk in Suid-Afrika met die Praktyk en Ideologie van die Apartheid in Historiese Perspektief (Amsterdam: Rodopi), 1981.

8 For one of the most lucid and comprehensive assessments on this subject, see F. Nyamnjoh, \#RhodesMustFall: Nibbling at Resilient Colonialism in South Africa (Mankom, Bamenda: Langaa Research and Publishing CIG), 2016.

9 See a brilliant reflection on these issues by a black young female theologian, L. Kobe, "Black Theology of Liberation (Is it the) Thing of the Past? A Theological Reflection on Black Students' Experiences." Missiology 6 (2) (2018): 288-303.

10 Adonis. Die Afgebreekte Skeidsmuur weer Opgebou, Stellinge. 
sal hul pastorale en apostolere bediening nou en vir die toekoms irrelevant wees vir die Suid-Afrikaanse situasie." 11

This frustration is experienced because the methodologies used in academia are not methodologies that take black narratives and black lived experiences seriously. How can they change the methodologies, it is claimed, when the African has nothing to contribute to knowledge production? Speaking on a similar subject, Kwesi Dickson argues that self-evaluation has not been done by the black church, and there is a ready explanation he avers for this. ${ }^{12}$

Dickson argues that "this is so because the historic churches (and also sometimes the Independent churches) tend to operate as if in the belief that it is in their interest to approximate as much as possible the church ethos as obtained in the West. The church's leadership [in Africa] has not shown any real inclination to wrestle with the presuppositions underlying the theological stance inherited from the West." ${ }^{\prime 3}$ The same can still be asserted today in Africa in general and in South Africa in particular.

I argue that one of the reasons why this debate is so protracted is because Africans themselves have imbibed a view that suggests that they (Africans) are not in a position of determining a trajectory that is going to lead to genuine African self-determination. This immediately reminded me of an observation once made by Bernard Magubane when he argued that the "supremacy of the whites, their values and civilisation, was only won when the cultural and value system of the defeated Africans was reduced to nothing and when Africans themselves loudly admitted the cultural hegemony of their white conquerors." 14

This white hegemony is kept alive, I argue, by an iconography that has shown over time that the self-determination of Africans is not to be sought in themselves, but that Africans are to be gratified with the benevolence of some whites. The same attitude can be linked to the question of divinity and begs why the idea of a black Jesus is such a detested idea, also especially to some blacks. Black Theology in South Africa realised these challenges in the late sixties and early seventies.

Although Black Theology as a subject did not percolate black congregations and communities thoroughly, it nevertheless remained an important hermeneutic of suspicion. Black Theology, it must be said, did not infiltrate black communities and

11 Adonis. Die Afgebreekte Skeidsmuur weer Opgebou, Stellinge.

12 K. Dickson, Theology in Africa (Maryknoll: Orbis Books), 1984, 107

13 Dickson, Theology in Africa, 107.

14 Magubane, cited in C. Ngcokovane, "The Socio-Cultural Analysis of the Origins and Development of Black Theology." In We are One Voice: Black Theology in the USA and South Africa, edited by S. Maimela and D. Hopkins (Braamfontein: Skotaville Publishers), 1989, 41. 
congregations primarily because of the economic dependence of black communities and congregations on an economy that is white controlled.

One can understand why Black Theology would not be welcomed in many congregations. This is so because Black Theology is a radical theological hermeneutic which questions the depiction of Jesus as white when historical scholarship has shown that Jesus did not at all resemble the picture we had come to embrace. Black Theology had as its counterpart, black consciousness which departed from the premise that suggested that God made no mistake in creating black people. To that end, black people were to be taught to accept themselves as being fully human and to instil into their personhood a sense of pride in their black bodies.

There comes a time that one must admit that certain things make it difficult to continue believing a lie, especially when one is confronted with a reality that suggests that to believe the lie in the face of truth, is pure folly. To a large extent, Christian communities build fences around what they deem to be their faith. These fences keep them safe, so they think, and so, they feed on a diet that prevents them from asking questions that might challenge the basis of their belief systems. Even if they get to the point of starting to question the very basis of their belief, they would always find ways of negating the newly discovered threat to their belief.

That tension is called different names in the various sciences. In psychology, that tension is called cognitive dissonance. ${ }^{15}$ When explained simply, this refers to the psychological tension that occurs when one holds mutually exclusive beliefs or attitudes; and that often motivates people to modify their thoughts or behaviours in order to reduce the tension. Using this very psychological lens in assessing the apartheid context and the theological and biblical support given by Dutch Reformed Church for apartheid in the 1970s, the likes of Boesak and others rebelled against a faith that could be complicit when such atrocities were committed.

Allan Boesak, in his dissertation, employs the psychologist Rollo May's usage of the concept "innocence." May makes a distinction between innocence and pseudoinnocence. ${ }^{16}$ While he admits that the former is well known, he argues that pseudoinnocence, as it is stated, refers to a form of innocence that is not genuine. ${ }^{17}$ This comes to the fore because it is believed that once someone has experienced something by witnessing it, the individual cannot depart from that which he/she had experienced and cannot deny what he/she has witnessed. Boesak then applies this to the context of apartheid South Africa. He challenges white liberals who were favoured by the system because of their whiteness and purported to be aligned with the plight of black people, while pretending that they were not seeing the injustices which were being perpetrated

15 L. Festinger. A Theory of Cognitive Dissonance (Stanford, CA: Stanford University Press), 1957.

16 A. Boesak, Farewell to Innocence: A Socio-Ethical Study on Black Theology and Power (Maryknoll: Orbis Books), 1981, 3.

17 Boesak, Farewell to Innocence, $3 \mathrm{f}$. 
against black people in fear of being deprived of the incentives that they enjoyed form the state. It is to this type of innocence that the people of South Africa have had to bid farewell. ${ }^{18}$

The reasoning of pseudo-innocence was arrived at through the use of biblical texts conveniently used by white masters to justify their serf roles and to call upon blacks to be obedient slaves, as was mandated by God through the biblical texts. James Cone, the father of Black Theology of Liberation, called for Black Theology and Black Power. ${ }^{19}$ This means that African Christians need to question why the Jesus presented to them is one who seems disinterested in their lived experiences. A Black Theology is therefore not enough if it does not guarantee black people a degree of power to will their own destiny. This is certainly never going to happen when blacks still worship a white Jesus that ostensibly asks blacks to sing Kumbaya my Lord, while languishing in their squalid and wretched conditions, created not by the divine, but by those who control the means of productions in the world.

To remain obedient to the laws which suggest that blacks must embrace their serf roles, black people have been encouraged to not think too much of the present world because there is a world over yonder. Those who disobey such a mandate are threatened with hell. ${ }^{20}$ Therefore, hell was created to scare people with the prospect of an eternal scourging fire. The very idea of someone burning in hell forever is so absurd and controverts the verity of grace, which appears so central in Christian faith. However, if you want people to behave in ways that keep others comfortably in positions that they occupy fraudulently, there invariably need to be some scare tactics employed to whip in line those who dare move out of line.

$\mathrm{Fear}^{21}$ is then given a prominent role in the agenda of the powerful. The whipping into line needed to happen publicly so that everyone could see the fate of anyone who attempted to challenge the privileged positions of some in society. James Cone, in one of his most recent works, likens the cross of Christ to the lynching tree in the USA. ${ }^{22}$ Many adherents of the Christian faith forget that the cross was in fact a form of capital punishment. It is not by chance that the spectacle of the crucifixion happened on a mountain for all potential rebels to see what happened to one of the foremost rebels.

Why was the public humiliation necessary? Because change was never going to come from the comfortable classes and those in positions of power and authority. Change was

18 Boesak, Farewell to Innocence.

19 J. Cone. Black Theology and Black Power (Maryknoll: Orbis Books), 1997.

20 The idea of fear is ubiquitous in Christian history and is clearly illustrated during the renaissance. See for instance the works of the Italian Dante Alighieri (1265-1321) during the renaissance era. His works on the hell is particularly known (cf. W. Estep, Renaissance and Reformation (Grand Rapids: Eerdmans), 1986, 22.

21 Cf. especially Cone's reflections on the lynching in the state of Arkansas where he was born and raised. J. Cone, The Cross and the Lynching Tree (Maryknoll: Orbis Books), 2011, xiii.

22 Cone, The Cross and the Lynching Tree. 
never going to come from the bourgeoisie. It was, therefore, very important that anyone in power should quell an impending revolution before it starts, and those most likely to lead such a revolution were the ones who had nothing at all to lose. This is the kind of people that Marx and Engels called the lumpenprolitariat. They described this group as the "dangerous class, the social scum, that passively rotting mass thrown off by the lowest layers of the old society."23

\section{Black Self-hate and the Perpetual Use of White Iconography}

This brings me to the issue of imagery, also known as iconography. Black Christians commemorate important events in the Christian calendar annually. One such commemoration, which stands out, is the Easter celebration. During this time, we notice a flurry of iconography bearing the Jesus who was crucified so that the sins of the world could be forgiven. What is disturbing to me is that the very imagery of Christ insists that this Christ has to be absolutely white.

One of the fundamental tenets of Black Theology is the emphasis on the lived experiences of black people. That blackness becomes a characteristic in black theological reflection, is because blacks have not provided an alternative to how the Christian God came to be presented to them. One of the first generation of theologians in South Africa, Sabelo Ntwasa, had this in mind when he reflected on the white god who had been imposed onto black people.

He wrote that "too many blacks have been beaten in every conceivable way until they have come to see themselves through the white man's eyes. Black is evil, dark, secret, and reeking of 'witchcraft.' Black culture and religion are heathen and immoral. Black people are inferior, stupid, untrustworthy, cowardly, cringing." ${ }^{24} \mathrm{He}$ continues, therefore, to say that "in this situation Black theologians have to be iconoclasts of the 'white' god. They have to tear down every image and symbol which, by presenting god as 'white,' reinforces this sense of human inferiority and worthlessness." 25

Scholarship is clear that the Jesus portrayed through the work of Michelangelo is not the Jesus who walked the lands of the Near Eastern World. Aylmer von Fleischer in his book, How Jesus Christ became White, apportions the reasoning for this whiteness to Michelangelo. He avers that "one of the major reasons the image of Jesus Christ was changed from black to white was due to some of Michelangelo's paintings. He was given a contract on 10th May 1508 by Pope Julius II to paint the ceiling of the Sistine

23 Marx and Engels cited in P. Hirst, "Marx and Engels on Law, Crime and Morality." Economy and Society 1 (1): 28-56.

24 S. Ntwasa and B. Moore, "The Concept of God in Black Theology." In Black Theology: The South African Voice, edited by B. Moore (London: C. Hurst and Co), 1973, 24-25.

25 Ntwasa and Moore, "The Concept of God in Black Theology," 25. 


\section{Tshaka}

Chapel. He used members of his family as models. For instance, his cousin was the model for Jesus Christ. The paintings were carried out between 1508 and 1512."26

The presentation of Jesus as white is problematic to Black Theology, because the projection of Jesus as white is political. It speaks to the conquest of black personhood which started already in 1441 when the first group of Africans were taken from the West African coast bound for the Christian land of Portugal, and Africans were given as trinkets to Prince Henry, sovereign of a Christian country. ${ }^{27}$ Black Theology cannot and does not want to ignore this great historical injustice, which contributed to the dislocation of the African from his/her personhood.

When I ask even my most learned friends why a white picture of Jesus is normative, and goes unchallenged, some of the responses I often get, mostly from black folk, is "who cares?" I invariably answer, "I care," and I find it rather repulsive that many black people do not care about the colour of Jesus. The white Jesus is a political picture meant to support the unjust wars of conquest in Africa. To just accept that without critiquing it, is to be theologically and politically ingenuous.

Not only is the retention of such pictures in African churches an admission that salvation will never come from those who look like us, but such pictures perpetuate the views that black people must constantly aspire to be what they are not. That justifies whiteness as being normative. The problem of white normativity is so deep that during Palm Sunday celebrations, social media is invariably ablaze with stories of some congregations even going to the extent of hiring whites to act as Jesus when he entered Jerusalem.

Black aesthetics is just as important as calls for the democratisation of cultures in the public sphere. ${ }^{28}$ If one feeds oneself a diet of "beauty as whiteness," that diet in the end translates into a view held by one. One just has to look at the definitions of the words white and black in the English dictionary to see how serious this matter contributes to black self-hate.

Doctors Kenneth and Mamie Clark in the 1940s experimented with dolls to assess children's attitudes about race. ${ }^{29}$ Although results showed that black girls always preferred white dolls and were of the view that black dolls were ugly, the practice of seeing whiteness as better and as the most preferred condition is a challenge for black

26 A. von Fleischer. How Jesus Christ Became White (Kindle edition), 2014.

27 D. Hopkins. "General Introduction." In The Cambridge Companion to Black Theology, edited by D. Hopkins and E. Antonio (Cambridge: Cambridge University Press), 2012, 4.

28 See a brilliant Master's dissertation by a promising young black theologian, K. Mokoena. "Black Aesthetics and the Son of Man Film." Unpublished MA dissertation (Pretoria: University of Pretoria), 2017.

29 K. Clark and M. Clark, "Emotional Factors in Racial Identification and Preference in Negro Children." The Journal of Negro Education 19 (3) (summer, 1950): 341-350. 
people even to this day. How can we ever expect our little girls to grow up loving themselves when they aspire for a version of beauty that does not resemble them?

\section{Conclusion}

Much of what has been argued in this piece has been said a thousand times in the past. The question is, why has this not been translated into action in black churches today? The reasons are many and varied. Some reasons are economic, others cultural, but I would like to emphasise one reason as the lack of authentic theological scholarship that speaks for Africa. Theological training, for example in the Uniting Reformed Church in Southern Africa (URCSA), is quite expensive, yet one very soon realises that the education received by Africans dislodges them from the very communities they are meant to ameliorate. This brings us back to the question of the ilk of methodology that is being used, as mentioned earlier. The problem of methodology, however, is not to be confined to theological education only; the same can be said of university education as a whole. Universities in Africa still insist that the worldviews of Europeans be made central in academic discourses. They argue that in the name of global standards, yet conveniently forget that what is global to one, is local to another. For instance, when Karl Barth was doing theology in Germany, he was certainly doing that theology from his local context, yet for the South African to do theology in South Africa, that theological reflection is not perceived to be global; nevertheless Barth's reflection is perceived to be global.

Africanisation asks that we foreground the lived experiences of Africans in our academic discourses. This means not simply taking as fact what we have come to inherit. URCSA can only address this if it has a curriculum that centres issues of the African and her continent. As it stands, I maintain that we do not have our own theological curriculum. ${ }^{30}$ What we have is a curriculum that we have borrowed verbatim from the Dutch Reformed Church. It is, therefore, not by chance that we also sing to that chorus of labelling Black Theology as so-called "third world theologies," although our primary objective is producing ministers for the South African context. Third world theology, in my view, is just another word for "not so important" theology.

The struggle for centring African epistemologies and worldviews continues even as we speak, and that struggle must wrestle seriously with the imagery of the divine we were forced to imbibe. The processes of translating these views into action will be faced by many challenges, and the most unsettling challenge which has contributed to this protracted discourse, is the challenge of white fragility. Talk about race unsettles not only whites, but black people themselves. I admit that this struggle is not for the faint hearted. So my question to those who ask, "who cares?" is that I ask again: "Why are you then so comfortable with a picture of a white Jesus that is conjured up each time

30 R. S. Tshaka, "The Black Church as the Womb of Black Liberation Theology? Why the Uniting Reformed Church in Southern Africa (URCSA) is not a Genuine Black Church?" HTS Teologiese Studies/Theological Studies 71 (1) (2015). 


\section{Tshaka}

you think of Jesus? If the colour of Jesus is not an issue, why are you so incensed at the suggestion that Jesus is black?"

\section{References}

Adonis, J. C. Die Afgebreekte Skeidsmuur weer Opgebou: Die Verstrengeling van die Sendingsbeleid van die Nederduitse Gereformeerde Kerk in Suid-Afrika met die Praktyk en Ideologie van die Apartheid in Historiese Perspektief. Amsterdam: Rodopi, 1981.

Appiah-Kubi, K., and S. Torres (eds). African Theology en Route. Maryknoll: Orbis Books, 1981.

Boesak, A. Farewell to Innocence: A Socio-Ethical Study on Black Theology and Power. Maryknoll: Orbis Books, 1981.

Cone, J. Black Theology and Black Power. Maryknoll: Orbis Books, 1997.

Cone, J. The Cross and the Lynching Tree. Maryknoll: Orbis Books, 2011.

Clark, K., and M. Clark. "Emotional Factors in Racial Identification and Preference in Negro Children." The Journal of Negro Education 19 (3) (1950). https://doi.org/10.2307/2966491.

Dickson, K. Theology in Africa. Maryknoll: Orbis Books, 1984.

Estep, W. Renaissance and Reformation. Grand Rapids: Eerdmans, 1986.

Festinger, L. A Theory of Cognitive Dissonance. Stanford, CA: Stanford University Press, 1957.

Hopkins, D., and E. Antonio (eds). The Cambridge Companion to Black Theology. Cambridge: Cambridge University Press, 2012. https://doi.org/10.1017/CCOL9780521879866.

Herschel, S. The Aryan Jesus: Christian Theologians and the Bible in Nazi Germany. Princeton: Princeton University Press, 2010. https://doi.org/10.6017/scjr.v5i1.1576.

Hirst, P. "Marx and Engels on Law, Crime and Morality." Economy and Society 1 (1) (2006): 28-56. https://doi.org/10.1080/03085147200000002.

Kobe, L. "Black Theology of Liberation (Is it the) Thing of the Past? A Theological Reflection on Black Students' Experiences.” Missiology 46 (2) (2018): 288-303. https://doi.org/10.7832/46-2-316.

Ngcokovane, C. "The Socio-Cultural Analysis of the Origins and Development of Black Theology." In We are One Voice: Black Theology in the USA and South Africa, edited by S. Maimela and D. Hopkins. Braamfontein: Skotaville Publishers, 1989. 


\section{Tshaka}

Ntwasa, S., and B. Moore. "The Concept of God in Black Theology." In Black Theology: The South African Voice, edited by B. Moore. London: C. Hurst and Co, 1973, 24-25.

Nyamnjoh, F. \#RhodesMustFall: Nibbling at Resilient Colonialism in South Africa. Mankom, Bamenda: Langaa Research and Publishing CIG, 2016. https://doi.org/10.2307/j.ctvmd84n8.

Mokoena, K. "Black Aesthetics and the Son of Man Film." Unpublished MA dissertation. Pretoria: University of Pretoria. 2017.

Tatum, B. "Why Are all the Black Kids Sitting together in the Cafeteria?” and other Conversations about Race. New York: Basic Books, 2003.

Tshaka, R. S. "Do our Theological Methodologies Help us to Deal with Situations of Violence in Black Communities, specifically Afrophobia." Journal of Theology for Southern Africa 138 (2010): 124-135.

Tshaka, R. S. "The Black Church as the Womb of Black Liberation Theology? Why the Uniting Reformed Church in Southern Africa (URCSA) is not a Genuine Black Church?" HTS Teologiese Studies/Theological Studies 71 (1) (2015). https://doi.org/10.4102/hts.v71i3.2800.

Von Fleischer, A. How Jesus Christ Became White. Kindle edition, 2014.

Wiredu, K. "Toward Decolonizing African Philosophy and Religion." African Studies Quarterly 1 (4) (1998): 17-46. 